\title{
PENYELENGGARAAN PENDIDIKAN TAHFIDZUL QUR'AN PADA ANAK USIA SEKOLAH DASAR DI PONDOK PESANTREN NURUL IMAN KOTA TASIKMALAYA
}

\section{IMPLEMENTATION OF TAHFIDZUL QUR'AN EDUCATION AT ELEMENTARY SCHOOL-AGED CHILDREN AT PESANTREN NURUL IMAN TASIKMALAYA}

\author{
Sumarsih Anwar \\ Balai Penelitian dan Pengembangan Agama Jakarta \\ Email: Sumarsihanwar5@gmail.com
}

Naskah diterima 15 Juni 2017, direvisi 20 Juli 2017, disetujui 31 Juli 2017

\begin{abstract}
This paper presents the result of research on Tahfidzul Qur'an Education at Elementary SchoolAged Children. The study aims at describing: 1) The process of organizing Tahfidz al-Quran education which includes: planning, organizing, implementation and supervision, at Tahfidzul Qur'an Islamic Boarding School, and 2) Supporting factors and obstacles in the implementation of Tahfidzul Qur'an education. The research location is in Tasikmalaya City with Tahfidzul Qur'an Nurul Iman Islamic Boarding school as the target. This is a qualitative research employing interviews, observation and documentation review to collect data. The results show that the implementation of Tahfidzul Qur'an education at Nurul Iman Islamic boarding school starting from planning, organizing, implementation and supervision (control), is in accordance with the principles as it has a clear definition of vision, mission, goals, targets and education strategies, understanding and clarity of the goals and obligations of the caregivers, students and parents. The process of learning Tahfidzul Qur'an uses several methods and approaches to allow children to be happy and free of coercion, creating a comfortable and conducive atmosphere in the education process at the Islamic boarding school. Supervision is done at any time and at certain times that have been programmed clearly.
\end{abstract}

Keywords: Education, Tahfidzul Qur'an, and Elementary School-Aged Children
Abstrak

Tulisan ini menyajikan hasil penelitian tentang Pendidikan Tahfidzul Qur'an pada Anak Usia Sekolah Dasar. Penelitian bertujuan untuk mendeskripsikan: 1) Proses penyelenggaraan pendidikan Tahfidz al-Quran yang meliputi: perencanaan, pengorganisasian, pelaksanaan dan pengawasan, pada Pondok Pesantren Tahfidzul Qur'an, dan 2) Faktor pendukung dan penghambat dalam penyelenggaraan pendidikan Tahfidzul Qur'an. Lokasi penelitian di Kota Tasikmalaya, dengan sasaran penelitian adalah Pondok Pesantren Tahfidzul Qur'an Nurul Iman. Jenis penelitian adalah kualitatif, dengan teknik pengumpulan data meliputi wawancara, pengamatan dan telaah dokumentasi. Hasil penelitian menunjukkan bahwa penyelenggaraan pendidikan Tahfidzul Qur'an di pondok pesantren Nurul Iman mulai dari perencanaan, pengorganisasian, pelaksanaan dan pengawasan (pengendalian), sudah sesuai dengan prinsipprinsip sudah memiliki rumusan yang jelas tentang visi, misi, tujuan, target dan strategi pendidikan, adanya pemahaman dan kejelasan akan tujuan dan kewajiban dari para pengasuh, santri dan juga orang tua. Dalam proses pembelajaran Tahfidzul Qur'an, dengan menggunakan beberapa metode dan pendekatan, sehingga anak tetap gembira dan tidak ada paksaan, tercipta suasana yang nyaman dan kondusif dalam proses pendidikan di pondok. Pengawasan dilakukan setiap saat dan pada waktu-waktu tertentu yang sudah terprogram dengan jelas.

Kata Kunci: Pendidikan, Tahfidzul Qur'an, dan Anak Usia Sekolah Dasar 


\section{PENDAHULUAN}

Al-Qur'an sebagai kitab suci umat Islam dari masa ke masa pertama kali diturunkan sampai sekarang terjaga keaslian dan kemurniannya walaupun dalam sejarah banyak golongan yang ingin menghancurkannya. Oleh karena itu betapa pentingnya peranan penghafal al-Quran di kalangan umat Islam, karena orang-orang yang mentadabburi dan menghafal al-Quran bertugas sebagai penjaga keaslian al-Quran agar jangan sampai al-Quran yang dijadikan dasar Islam ini mudah diselewengkan oleh pihak-pihak lain yang menginginkan kehancuran umat Islam. Memang kemurnian al-Quran ini sendiri sudah dinash-kan oleh Allah sejak diturunkannya sampai hari kiamat kelak, tetapi kita sebagai umat manusia juga terlibat untuk menjaga kemurniannya sebagaimana firman Allah:"Sesungguhnya Kamilah yang menurunkan al-Qur'an dan pasti Kam (ipula) yang memeliharanya." (QS Al-Hijr: 9)

Meskipun dalam ayat tersebut menjadi jaminan Allah terhadap pemeliharaan keaslian al-Quran, hal ini tidak berarti umat Islam terlepas dari tanggung jawab dan kewajiban memelihara kemurniannya. Pada dasarnya umat Islam tetap berkewajiban untuk secara riil dan konsekuen untuk berusaha memeliharanya. Memang, pada saat ini sudah banyak kaset dan VCD yang mampu menyimpan teks al- Qur'an, begitu juga banyaknya al-Qur'an yang sudah beredar di masyarakat. Hal itu tidak menutup kemungkinankemurnianayat-ayat al-Qur'an akan diusik dan diputar balikkan oleh musuh-musuh Islam, apabila umat Islam sendiri tidak mempunyai kepedulian terhadap pemeliharaan kemurnian al-
Qur'an. Salah satu usaha nyata dalam proses pemeliharaan kemurnian al-Qur'an itu ialah dengan menghafalkannya. ${ }^{1}$

Oleh karena itu, lembaga pendidikan Islamharusmenyiapkan penghafal al-Quran sejak usia anak-anak. Karena hafalan anak kecil walaupun agak lambat tetapi ingatan mereka biasanya sangat kuat. Dan jika biasa dibaca setiap hari, hafalan mereka semakin kuat, hingga sudah di luar kepala, Seperti kata pepatah : belajar waktu kecil bagaikan mengukir di atas batu". Maka dengan itu diperlukan adanya suatu pendidikan al-Quran, khususnya pembelajaran hafalan al-Quran bagi anak-anak.

Penyelenggaraan pembelajaran menghafal al-Quran bagi usia anak bukanlah persoalan mudah, melainkan dibutuhkan pemikiran dan analisis mendalam dari hal perencanaan, metode, alat dan sarana prasarana, target hafalan, evaluasi hafalan dan sebagainya. Oleh karena itu dibutuhkan juga pengelolaan (manajemen) pembelajaran menghafal al-Quran anak yang betul-betul dapat memahami kondisi anak. Sehingga pembelajaran menghafal al-Quran yang dilaksanakan dapat mencapai target hafalan yang diharapkan dan sesuai dengan tujuan yang ditetapkan. Dan nantinya harapan orang tua dan guru agar kelak mereka menjadi generasi cendekia yang hafal alQuran dapat terwujud.

Pendidikan al-Quran dalam sejarah pendidikan Islam di Indonesia sudah diselenggarakan orang tua, guru Agama Islam, dan tokoh-tokoh agama Islam jauh sebelum merdeka dengan sebutan ngaji ba'da magrib. Hampir semua anak-anak baik lelaki

${ }^{1}$ Ahsin, W. Al Hafizh. 2000; Bimbingan Praktis Menghafal Al Qur'an, Jakarta: bumi Aksara, h.22. 
maupun perempuan di kota maupun desa sampai perkampungan sebelum matahari terbenam sudah mandi berpakaian bersih bahkan ada yang langsung mengapit alQuran sebelah kanan bagi perempuan, sementara laki-laki menggunakan sarung dan peci sambil mengapit al-Quran ditangan kanannya beramai-ramai menuju rumah kyai, tuan guru ada yang menuju Surau, Mushalla bahkan Masjid untuk belajar alQuran.

Kehadiran Pendidikan al-Qur'an, bermula dari kegelisahan para tokoh agama dan pemerintah terhadap penurunan kemampuan generasi dalam membaca dan memahami kitab suci al-Quran serta penerapannya dalam kehidupan seharihari. Maka pada tahun 1982 diterbitkan SKB Menteri Dalam Negeri dan Menteri Agama Nomor 128 dan 44 A tahun 1982, tentang "Usaha Peningkatan Kemampuan Baca Tulis Huruf al-Quran Bagi Umat Islam dalam rangka Peningkatan Penghayatan dan Pengamalan al-Quran dalam Kehidupan Sehari-hari".

Kebijakan tersebut dikuatkan dengan adanya regulasi satuan Pendidikan Pendidikan al-Quran melalui Peraturan Pemerintah RI Nomor 55 Tahun 2007. Dalam PP tersebut dikatakan bahwa satuan Pendidikan al-Quran bertujuan meningkatkan kemampuan peserta didik membaca, menulis, memahami, dan mengamalkan kandungan al-Quran (Pasal 24 ayat1). Pendidikan Al-Quran terdiri dari Taman Kanak-Kanak al-Quran (TKQ), Taman Pendidikan al-Quran (TPQ), Ta'limul Qur'an lil Aulad (TQA), dan bentuk lain yang sejenis (Pasal 24 ayat 2). Pendidikan al-Quran dapat dilaksanakan secara berjenjang dan tidak berjenjang (Pasal 24 ayat 3). Penyelenggaraan pendidikan alQuran dipusatkan di masjid, mushalla, atau ditempat lain yang memenuhi syarat (Pasal 24 ayat 4). Kurikulum pendidikan al-Quran adalah membaca, menulis dan menghafal ayat-ayat al-Qur'an, tajwid, serta menghafal doa-doa utama (Pasal 24 ayat 5). Pendidik pada pendidikan al-Quran minimal lulusan pendidikan diniyah menengah atas atau yang sederajat, dapat membaca alQuran dengan tartil dan menguasai teknik pengajaran al-Qur'an (Pasal 24 ayat 6).

Jauh sebelum itu, beberapa pondok pesantren yang sebelumnya khusus menyelenggarakan pendidikan Tahfidz alQuran untuk anak usia sekolah yang sampai 2014 ini sebanyak 1061 pondok pesantren (Direktorat PD Pontren : 2015). Di sisi lain, masyarakat juga mendirikan "Rumah Tahfidz" secara mandiri yang belum terakomodir dan terdata oleh Kementerian Agama, salah satunya Rumah Tahfidz Daarul Quran yang sudah menjamur di berbagai tempat, yang digagas oleh Pondok Pesantren Penghafal Al-Quran (PPPA) dibawah binaan Ust Yusuf Mansur. Ide dasarnya untuk mencari bibit dan mencetak para penghafal al-Quran dengan melibatkan potensi masyarakat yang ada. Rumah Tahfidz Daarul Quran menjadi salah satu sarana membangun generasi yang Qurani dan berakhlakul karimah. Pada tahun 2013 sudah berdiri 300 rumah tahfidz yang didirikan secara mandiri oleh masyarakat di seluruh Indoensia dengan supervisi dari PPPA Daarul Quran.

Kehadiran Taman Pendidikan Al-Qur'an, Rumah Tahfidz dan Pondok Pesantren Tahfidz Al-Quran sejalan dengan Renstra Pendis tahun 2015-2019 isu strategis nomor 7 tentang Peningkatan Pendidikan 
Keagamaan yang diproyeksikan oleh Direktorat Pendidikan Diniyah dan Pondok Pesantren melalui program launcing 10.000 santri hafidz al-Quran dalam kurun waktu 2015-2020 dengan sasaran santi usia sekolah (7-18 tahun). Pondok pesantren takhfidz, TPQ dan rumah takhfidz tersebar di beberapa wilayah Indonesia. Salah satu propinsi yang memiliki pondok pesantren takhfidz, TPQ dan rumah takhfidz adalah Propisi Jawa Barat, dan salah satu kota/kabupaten yang memiliki lembaga pendidikan takhfidz dimaksud adalah Kota Tasikmalaya.

Dari pemikiran di atas, kajian secara mendalam tentang berbagai persoalan dalam penyelenggaraan pendidikan Tahfidzd alQuran yang berkembang di masyarakat, terutama pada anak usia sekolah dasar layak dilakukan. Oleh karena itu, rumusan masalah penelitian adalah model penyelenggaraan pendidikan Tahfidzul Al-Qur'an berbasis komunitas Pondok Pesantren Tahfidzul AlQur'an, terutama bagi anak usia sekolah dasar yang tumbuh kembang di masyarakat belum terdata secara holistik dan representatif. Sesuai dengan rumusan masalah tersebut, maka tujuan penelitian adalah untuk mengetahui dan mendeskripsikan tentang: 1) Proses penyelenggaraan pendidikan Tahfidz al-Quran terutama bagi anak usia sekolah dasar yang meliputi: perencanaan, pengorganisasian, pelaksanaan dan pengawasan, 2) Faktor pendukung dan penghambat dalam penyelenggaraan pendidikan Takhfidzul Qur'an khusus anak usia sekolah dasar.

Penelitian ini sejalan dengan isu strategis Renstra Pendidikan Islam, Dirjen Pendis Tahun 2015-2019, yaitu meningkatkan mutu santri pendidikan diniyah dan pondok pedantren melalui pemberian beasiswa Tahfizh al-Qur'an (Program Beasiswa Tahfizh al-Qur'an). Sehingga bisa dimanfaatkan sebagai bahan masukan dan pertimbangan Kementerian Agama dalam menetapkan kebijakan layanan Pendidikan al-Quran.

\section{METODOLOGI PENELITIAN}

Jenis penelitian adalah kualitatif dengan pendekatan fenomenologis dimana peneliti berusaha memahami arti peristiwa dan kaitan-kaitannya terhadap orang-orang yang berada situasi tertentu. ${ }^{2}$ Hal ini dimaksudkan untuk menelusuri fenomena dan memperoleh data yang ada di lapangan sehubungan dengan manajemen penyelenggaraan pendidikan Tahfidz alQuran.

Penelitian dilakukan di Pondok Pesantren Tahfidhul Qur'an Nurul Iman Musyadadiyah kota Tasikmalaya. Lembaga ini dipilih karena salah satu pesantren di kota Tasikmalaya yang sudah memiliki program Tahfidhul Qur'an bagi anak usia sekolah, mulai dari usia 6 tahun - 12 tahun. Pengumpulan data dalam penelitian ini menggunakan teknik observasi, wawancara dan dokumentasi. Observasi dilakukan dengan cara mengamati dan mencatat secara sistematik terhadap gejala yang tampak di balik penyelenggaraan pendidikan tahfidz al-Qur'an, baik secara langsung maupun tidak langsung. Teknik ini digunakan untuk menggali data langsung dari objek penelitian, diantaranya guru tahfidz ketika mengajar, santri dan fasilitas pembelajaran. Dalam penelitian ini peneliti mengamati

${ }^{2}$ Lexy, Moeleong, (2005). Metode Penelitian Kualitatif, Bandung: PT. Remaja Rosdakarya, h. 17.. 
kegiatan guru-guru tahfidz dan santri, baik ketika pembelajaran berlangsung di kelas maupun di luar kelas, serta kehidupan santri di dalam pondok.

Wawancara dimaksudkan untuk menggali informasi secara langsung kepada informan (pemberi informasi). Sebagai informan adalah: 1) Pimpinan Pesantren Tahfidz untuk mendapatkan gambaran tentang profil lembaga dan tujuan pembelajaran tahfidz alQuran, Serta peran dan tugas pimpinan dalam pembelajaran tahfidz al-Quran., 2) Guru/Ustadz (pengasuh) tahfidz untuk mendapatkan informasi tentang perencanaan, pelaksanaan dan evaluasi pembelajaran tahfidz al-Quran dan 3) Pihak lain yang berkaitan dengan perolehan data dalam penelitian ini (seperti: Kepala Seksi Pendidikan Diniyah Pondok Pesantren dan pengurus Forum Pondok Peantren). Teknik dokumentasi, untuk mencari data yang berupa catatan atau tulisan yang berkaitan dengan penyelenggaraan pendidikan tahfidz al-Quran, diantaranya: 1) Profil, visi, misi dan tujuan pendidikan, 2) Kurikulum pembelajaran tahfidz al-Quran, 3) Dokumen perangkat perencanaan pembelajaran, 4) File atau dokumen mengenai data guru dan santri/siswa, 5) Foto-foto gedung atau rumah tempat pembelajaran berlangsung dan 6) Dokumen penting lainnya yang berkaitan dengan tema penelitian.

\section{Kerangka Koseptual}

\section{Pendidikan Tahfidzul Qur'an}

Pengertian Pendidikan Kamus Bahasa Indonesia, 1991:232, Pendidikan berasal dari kata "didik", Lalu kata ini mendapat awalan kata "me" sehingga menjadi "mendidik" artinya memelihara dan memberi latihan. Dalam memelihara dan memberi latihan diperlukan adanya ajaran, tuntutan dan pimpinan mengenai akhlak dan kecerdasan pikiran. Menurut UU No.20 tahun 2003 tentang sistem Pendidikan Nasional, Pendidikan adalah usaha sadar dan terencana untuk mewujudkan suasana belajar dan proses pembelajaran agar peserta didik secara aktif mengembangkan potensi dirinya untuk memiliki kekuatan spiritual keagamaan, pengendalian diri, kepribadian, kecerdasan, akhlak mulia, serta keterampilan yang diperlukan dirinya, masyarakat, bangsa dan negara.

Sedangkan menurut Syed Muhammad Naquib Al-Attas, pendidikan adalah suatu proses penamaan sesuatu ke dalam diri manusia mengacu kepada metode dan sistem penamaan secara bertahap, dan kepada manusia penerima proses dan kandungan pendidikan tersebut. Dari definisi dan pengertian itu ada tiga unsur yang membentuk pendidikan yaitu adanya proses, kandungan, dan penerima. Kemudian disimpulkan lebih lanjut yaitu "sesuatu yang secara bertahap ditanamkan ke dalam diri manusia". Jadi definisi pendidikan Islam adalah, pengenalan dan pengakuan yang secara berangsur-angsur ditanamkan ke dalam diri manusia, tentang tempattempat yang tepat dari segala sesuatu di dalam tatanan penciptaan, sehingga membimbing ke arah pengenalan dan pengakuan tempat Tuhan yang tepat di dalam tatanan wujud dan kepribadian.

Tahfidzul Qur'an terdiri dari 2 (dua) kata yaitu tahfidz dan al-Qur'an. Kata tahfidz merupakan bentuk isim masdar dari fiil madhi/dari kata hafadza, yuhafidzu tahfidzan, 
yang mengandung makna menghafalkan atau menjadikan hafal (Yunus, 2005). ${ }^{3}$ Sedangkan menurut Abdul Azis \& Abdul Rauf, definisi tahfidz atau menghafal adalah proses mengulang sesuatu, baik dengan membaca atau mendengar. Pekerjaan apapun jika sering diulang pasti menjadi hafal (bukuinsfirasi.blogspot.com/2014). ${ }^{4}$

Secara etimologi (bahasa), al-Qur'an berasal dari bahaa Arab, yaitu qaraa-yaqrauquraanan, yang artinya bacaan. Hal itu dijelaskan dalam Surat Al Qiyamah (ayat 17-18), yang artinya: "Sesungguhnya Kami yang akan mengumpulkannya (di dadamu) dan membacakannya. Apabila Kami telah selesai membacakannya, maka ikutilah bacaannya itu. ${ }^{5}$ Sedangkan pengertian secara terminologi (istilah), al-Qur'an adalah kalamullah yang diturunkan kepada Nabi Muhammad SAW sebagai mukjizat yang tertulis dalam lembaran-lembaran, yang diriwayatkan secara mutawattir, dna membacanya merupakan ibadah.

Setelah memahami pengertian tahfidz/menghafal al-Qur'an di atas, dapat disimpulkan bahwa menghafal al-Qur'an adalah suatu proses untuk memelihara, menjaga dan melestarikan kemurnian al-Qur'an yang diturunkan kepada Raulullah SAW, di luar kepala agar tidak terjadi perubahan dan pemalsuan serta dapat menjaga dari kelupaan baik secara keseluruhan ataupun sebagiannya.

${ }^{3}$ Yunus, Mahmud. (1972). Kamus Arab Indonesia, Jakarta: Hidakarya Agung, h. 324..

${ }^{4}$ Abdul Azis \& Abdul Rauf dalam bukuinsfirasi. blogspot.com/2014.

${ }^{5}$ Departemen Agama RI, Al Qur'an dan Terjemahnya, 2006, Jakarta: Direktur Jenderal Bimbingan Masyarakat Islam, h.854

\section{Kaidah Menghafal Al-Qur'an}

Menghafalal-Qur'an bukanlah pekerjaan yang mudah untuk dilaksanakan, jika tidak meluangkan waktu, usaha dan segenap kemampuan. Jika segala sesuatu dimulai dengan niat yang sungguh-sungguh pastinya akan memperoleh keberhasilan. Begitu juga dalam menerapkan program Tahfidzul Qur'an pada jenjang awaliyah, yang merupakan jenjang usia anak pada sekolah tingkat dasar. Oleh Raghib al Sirjani, disebutkan bahwa kaidah-kaidah yang ditetapkan merupakan kaidah-kaidah Ijtihadiyyah, yang berarti mengandung pengertian terbuka kepada tambahan-tambahan dan semua orang berhak menurunkan timba ukurannya masing-masing, atau dapat menambah caracara yang baru, atau kaidah-kaidah lainnya yang telah teruji dan berguna membantu umat untuk menghafal al-Qur'an (Raghib dalam Sofwan, 2014). ${ }^{6}$

Lebih lanjut disebutkan, terdapat kaidah pokok dan kaidah pendukung. Kaidah pokok merupakan kaidah-kaidah yang diyakini tidak bisa dihindari selama-lamanya oleh penghafal al-Qur'an. Sedangkah kaidah pendukung adalah adalah kaidah-kaidah yang bisa menerima akan perubahan, tambahan dan penghapusan sampai batasbatas tertentu. Namun demikian, dengan berpegang kepada kedua kaidah tersebut akan membuahkan hasil yang sangat baik.

Kaidah-kaidah pokok dalam menghafal al-Qur'an meliputi: 1) Ikhlas; merupakan kaidah terpenting dalam menghafal alQur'an. Semua pendidik diharapkan dalam memberikan pengajaran kepada anak didik, tidak untuk mengharapkan kedudukan

${ }^{6}$ Raghib al Sirjani dalam M.Sofwan, 2014digilib. unisby.ac.id, diakses tanggal 27 Mei 2015. 
dengan al-Qur'an atau posisi yang tinggi di atas manusia atau lebih unggul dari temanteman sebayanya. 2) Tekad yang kuat; hal ini menjadi pekerjaan orang tua agar senantiasa mengenalkan al-Qur'an kepada anak sejak usia dini atau sebelum mereka masuk ke sekolah dasar. Keinginan saja tidaklah cukup, ia mesti diiringi oleh kemauan yang kuat untuk melakukannya.3) Paham akan keutamaan menghafal al-Qur'an;. 4) Berdo'a kepada Allah; berdoa kepada Allah dengan ikhlas dan jujur 4) Memperhatikan kaidahkaidah tajwid; membaguskan (tajwid) bacaan al-Qur'an; dan 5) Membaca al-Qur'an secara rutin; berusaha menamatkan bacaan al-Qur'an dalam jangka waktu tertentu (bulanan, mingguan, harian ataupun halaman) merupakan hal yang baik untuk memulai hafalan al-Qur'an. Tetapi untuk pendidikan anak-anak tentunya berbeda, yaitu lebih menuntun anak-anak didik lebih sering membaca al-Qur'an.

Beberapa kaidah pendukung dalam menghafal al-Qur'an adalah: 1) Perencanaan yang baik dan jelas, 2)) Bekerja sama dengan orang lain, 3) Mendahulukan menghafal surat-surat yang pendek dan mudah, 4) Tetap pada satu jenis mushaf, 5) Jangan berpindah ke surat yang baru sebelum yang lama hafal dengan lancar, dan f) Mengikuti perlombaan-perlombaan hafalan al-Qur'an.

Senada dengan kaidah-kaidah yang dikemukakan oleh Raghib al Sirjani, Badwilan menyebutkan juga tentang kaidah-kaidah umum yang diharapkan bisa membantu mereka yang ingin menghafal al-Qur'an, agar mereka mendapat kedudukan yang tinggiatau sebagian darinya jika tidak bisa dicapai seluruhnya. ${ }^{7}$ Tekad itu harus datang kepada seorang yang memiliki keteguhan. ${ }^{8}$ Beberapa kaidah penting yang harus diperhatikan adalah: 1) Konsisten dengan satu mushaf hafalan, 2) Berguru pada Ulama yang Hafidz, 3) Memilih dan memanage waktu dengan baik, 4) Menentukan target hafalan setiap hari, 5) Mengulangi secara rutin, dan 6) Penggunaan tahun-tahun yang tepat untuk menghafal

Lebih lanjut, menurut Badwilan, tahun yang tepat untuk menghafal al-Qur'an yang benar-benar telah disepakati, yaitu dari umur 5 tahun hingga kira-kira 23 tahun. Alasannya, manusia pada usia ini daya hafalannya bagus sekali, bahkan masa ini merupakan tahun-tahun menghafal cepat. Menghafal pada usia ini sangat cepat, dan kelupaan masih lambat sekali. ${ }^{9}$

Pendapat lain adalah Ahsin, bahwa ada beberapa hal yang harus dipenuhi sebelum seseorang memasuki periode menghafal al-Qur'an, diantaranya adalah: 1) Mampu mengosongkan benaknya dari pikiranpikiran dan teori-teori, atau permasalahan yang sekiranya akan mengganggu, 2) Niat yang ikhlas, 3) Memiliki keteguhan dna kesabaran, 4) Istiqomah, 5) Menjauhkan diri dari maksiat dan sifat-sifat tercela, 6) Ijin orang tua, wali, atau suami, dan 7) Mampu membaca dengan baik (1994). ${ }^{10}$ Sugianto mengemukakan, seorang penghafal hendaknya memenuhi beberapa syarat yang berhubungan dengan naluri insaniyah

${ }^{7}$ Badwilan Ahmad Salim, 2009, Panduan Cepat Menghafal Al Qur'an, Yogyakarta: Diva Press, h. 199202.

${ }^{8}$ Badwilan, Ibid. h. 105.

${ }^{9}$ Ibid. h. 116.

${ }^{10}$ Ahsin, W. Al Hafizh, 2000, Bimbingan Praktis Menghafal Al Qur'an, Jakarta: Bumi Aksara, h. 48-54. 
yang benar dna baik, mendapat ijin dari orang tua, wali dan suami bagi wanita yang telah menikah, memiliki sifat mahmudah, kontinuitas dalam menghafal al-Qur'an, sanggup memelihara hafalan, dan memiliki mushaf sendiri. ${ }^{11}$

Dari beberapa pendapat di atas, dapat disimpulkan bahwa seorang penghafal alQur'an harus mempunyai syarat sebagai berikut: 1) Niat yang ikhlas, 2) Memiliki keteguhan dan kesabaran, 3) Istiqomah (kontinuitas), dan 4) Menjauhkan diri dari maksiat dan sifat tercela.

\section{Metode Tahfidzul Qur'an}

Ada beberapa metode yang bisa dikembangkan dalam rangka mencari alternative terbaik untuk menghafal alQur'an. Menurut Ahsin), ada beberapa metode untuk memudahkan menghafal alQur'an (Ahsin, 2000). ${ }^{12}$ Berikut penjelasan secara singkat: 1) Metode Wahdah; menghafal satu persatu terhadap ayat-ayat yang hendak dihafalnya. Untuk mencapai hafalan awal setiap ayat bisa dibaca sebanyak 10 (sepuluh) kali atau lebih sehingga proses ini mampu membentuk pola dalam bayangannya. Dengan demikian, penghafal akan mampu mengkondisikan ayat-ayat yang dihafalkannya bukan saja dalam bayangan akan tetapi hingga membentuk gerak refleks pada lisannya. 2) Metode Kitabah; artinya menulis. Pada metode ini penghafal menulis terlebih dahulu ayat-ayat yang akan dihafalnya. Kemudian ayat-ayat tersebut dibaca hingga lancar dan benar bacaannya. Metode ini cukup praktis dan baik, karena disamping membaca dengan lisan, aspek visual menulis juga akan sangat membantu dalam meepercepat terbentuknya pola hafalan dalam bayangannya. 3) Metode Sima'i; artinya mendengar. Yang dimaksud dengan metode ini adalah mendengarkan sesuatu bacaan untuk dihafalkannya. Metode ini akan sangat efektif bagi penghafal yang mempunyai daya ingat ekstra., terutama penghafal tunanetra, atau anak-anak yang masih di bawah umur yang belum mengenal baca tulis al-Qur'an. 4) Metode Gabungan; metode ini merupakan metode gabungan antara metode wahdah dan metode kitabah. Hanya saja kitabah di sini lebih memiliki fungsional sebagai uji coba terhadap ayatayat yang telah dihafalnya. Maka dalam hal ini, setelah selesai menghafal ayat yang dihafalnya, kemudian ia mencoba menuliskannya di atas kertas yang disediakan untuknya.. dan 5) Metode Jama'; metode jama' adalah cara menghafal yang dilakukan secara kolektif, yakni ayat-ayat yang dihafal secara kolektif atau bersamasama, dengan dipimpin seorang instrtuktur. Cara ini termasuk metode yang baik untuk dikembangkan, karena akan dapat menghilangkan kejenuhan, disamping akan membantu menghidupkan daya ingat terhadap ayat-ayat yang dihafalkannya.

Menurut Munjahid ada metode yang dapat digunakan bagi para penghafal, yakni metode menghafal dengan pengulangan penuh, metode menghafal dengan tulisan, metode menghafal dengan memahami makna, metode menghafal dengan bimbingan guru. ${ }^{13}$
11 Iham Agus Sugianto, 2004, Kiat Praktis Menghafal Al Qur'an, Bandung: Munjahid Press, 52.

${ }^{12}$ Ahsin, Op.Cit. h. 63.
${ }^{13}$ Munjahid, Tanpa tahun; Strategi menghafal Al Qur'an 10 Bulan Khatam, Yogyakarta: Idea Press, 77-80. 


\section{Perkembangan Anak Sekolah Dasar}

Fase kanak-kanak tengah dan akhir adalah fase perkembangan yang berlangsung kira-kira umur 6 sampai 11 tahun, sama dengan masa usia sekolah dasar. Anak-anak menguasai keterampilan-keterampilan dasar membaca, menulis dan berhitung. Secara formal mereka mulai memasuki dunia yang lebih luas dengan budayanya. Pencapaian prestasi menjadi arah perhatian pada dunia anak, dan pengendalian diri sendiri bertambah pula.

Beberapa ahli mengemukakan teorinya tentang fase perkembangan anak usia sekolah dasar, salah satunya adalah Robert E Slavin. Menurut Slavin ${ }^{14}$, fase perkembangan meliputi beberapa aspek, yaitu: Pertama, Perkembangan Fisik; Ketika anak-anak melewati kelas-kelas sekolah dasar perkembangan fisik mereka mengalami perlambatan jika dibandingkan dengan masa kanak-kanak awal. Anakanak berubah relative sedikit ukuran tubuhnya selama masa sekolah dasar. Anak perempuan lazimnya sedikit lebih pendek dan lebih ringan daripada anak laki-laki hingga sekitar usia 9 tahun ketika tinggi dan bobot badan kira-kira sama untuk anak laki-laki dan anak perempuan. Pada saat anak-anak memasuki sekolah dasar, mereka telah mengembangkan banyak kemampuan motoric dasar yang mereka butuhkan untuk menyeimbangkan badan, berlari, melompat dan melempar.

Kedua, Perkembangan Kognisi; Menurut SieglerdalamSlavin, antarausia5dan7tahun,

${ }^{14}$ Robert E Slavin, 2011 Psikologi Pendidikan Edisi ke Sembilan. PT Indeks; Jakarta dalam

${ }^{h}$ ttp://misbariumsida.blogspot.co.id/2014/01/ fase-fase-perkembangan-anak-sekolah.html. proses pemikiran anak-anak mengalami perubahan penting. Ini adalah periode peralihan dari tahap pemikiran praoperasi ke tahap operasi konkret. Perubahan ini memungkinkan anak-anak melakukan secara mental sesuatu yang sebelumnya dilakukan secara fisik. Tidak semua anak mengalami peralihan ini pada usia yang sama dan tidak satu pun anak berubah dari tahap satu ke tahap berikut dengan cepat. Anak-anak sering menggunakan perilaku kognisi yang merupakan ciri khas dua tahap perkembangan pada saat yang sama. Ketika melangkah dari satu ke tahap berikutnya karakteristik tahap sebelumnya dipertahankan ketika perilaku kognisi tahap yang lebih tinggi berkembang. Anakanak usia sekolah dasar dengan pesat mengembangkan kemampuan daya ingat dan kognisi termasuk kemampuan metakognisi, yaitu kemampuan memikirkan pemikiran mereka sendiri dan mempelajari cara belajar.

Ketiga, Perkembangan Sosioemosi; Pada saat anak memasuki usia sekolah dasar, mereka telah mengembangkan kemampuan pemikiran, tindakan, dan pengaruh social yang lebih rumit. Anak-anak pada dasarnya bersikap egosentris dan dunia mereka adalah dunia rumah, keluarga, dan mungkin prasekolah.

\section{Manajemen}

Fungsi manajemen yang meliputi Planning (Pengorganisasian), Organizing (pengorganisasian), Actuating (Pelaksanaan/ penggerakan), dan Controliing (Pengawasan) dapat dijelaskan secara ringkas sebagai berikut: 1) Planning (Perencanaan); adalah mennetukan tujuan-tujuan yang hendak 
dicapai selama satu masa yang akan datang dan apa yang harus diperbuat agar dapat mencapai tujuan itu. ${ }^{15}$ Jadi masalah perencanaan adalah masalah "memilih" yang terbaik dari beberapa alternative yang ada. $^{16}$ 3) Organizing (Perencanaan); Tujuan pengorganisasian adalah membantu orangorang bekerjasama secara efektif dalam wadah organisasi atau lembaga. ${ }^{17}$ 2) Actuating (menggerakkan/pelaksanaan); manajemen untuk mmebat orang lain suka dan dapat bekerja secara ihklas serta bergairah untuk bekerjasama dalam rangka untuk mencapai tujuan organisasi sesuai dengan rencana dan pengorganisasian. Dalam situasi sekolah (lembaga pendidikan), semua ini dapat dilihat dari kualitas manajemen instruksional, sehingga pelayanan belajar dan evaluasi kemajuan belajr dapat dilaksanakan memenuhi standar kualitas yang kompetitif.18 ${ }^{4}$ ) Controlling (pengawasan); mengukur pelaksanaan dengan tujuan-tujuan menentukan sebabsebab penyimpangan dan mengambil tindakan-tindakan korektif di mana perlu. ${ }^{19}$

15 Terry \& Leslie, 2013, Dasar-dasar Manajemen, Penerjemah: G.A. Ticoalu (Jakarta: PT. Bumi Aksara, h. 9

${ }^{16}$ Malayu S.P. Hasibuan, 2011, Manajemen Dasar Pertimbangan dan Masalah, Jakarta: PT. Bumi Aksara, h.40.

${ }^{17}$ Sudjana, 2004, Manajemen Program Pendidikan, Bandung: Falah Production, 2004, h.106.

${ }^{18}$ Musfirotun Yusuf, 2012, Manajemen Pendidikan, Pekalongan: STAIN Pekalongan Press: 2012, h.25-26.

${ }^{19}$ Terry \& Leslie: Op.Cit, h. 10

\section{HASIL DAN PEMBAHASAN}

\section{Profil Pondok Pesantren Tahfidzul Qur'an Nurul Iman}

Pondok Pesantren (PP) Nurul Iman yang berada di kota Tasikmalaya dipimpin oleh KH. Dede Khoerudin, alumni Pesantren Darut Tauhid, Arjowinangun Cirebon (6 tahun). Menjelang kelas II MA, belajar ke PP Darul Qur'an Tahasus Takhfidz, Tegal (2 tahun). Kembali ke PP Darut Tauhid Cirebon untuk melanjutkan pendidikan pada jenjang Madrasah Aliyah (MA). Setelah lulus MA, beliau melanjutkan pendidikan agamanya ke Pondok Pesantren Musyadadiyah Garut, sambil melanjutkan kulyah di STAI Tarbiyah Tasikmalaya. Tahun 2010 melanjutkan pendidikan pasca Sarjana di PTIQ Jakarta Program Jarak Jauh, selesai tahun 2013. Di saat yang sama, beliau mendapat amanah untuk memanfaatkan tanah wakaf dari pimpinan PP Musyadadiyah Garut seluas 2 hektar, untuk mendidirikan sebuah lembaga pendidikan Islam yang diberi nama Pondok Pesantren Nurul Iman Tahfidz Qur'an (PP NI Musyadadiyah), yang berlokasi di Kota Tasikmalaya.

Visi pondok pesantren yaitu Mencetak manusia yang berilmu amalyah, dan beramal ilmiyah". Sedangkan misinya adalah mencetak orang-orang yang mampu membaca dan menghafal al-Qur'an dengan baik dan benar. Sesuai dengan visi dan misi tersebut, maka strategi yang diterapkan adalah: 1) Memperkenalkan al-Qur'an agar dicintai dan mencintai orang yang membacanya, 2) Selalu bersama dengan alQur'an di dalam situasi apapun, dan 3) Mau memberikan yang diterima kepada orang lain walaupun hanya 1 (satu) ayat. 
Pondok pesantren yang telah memiliki Piagam Penghargaan dari Kementerian Agama Kota Tasikmalaya pada tahun 2009 M/1431 H dengan Nomor Statistik Pondok Pesantren: 500032780228, mempunyai motto: "Mencintai dan Menghafal Al Qur'an”. Lokasi Pondok Pesantren Nurul Iman berada di Jalan Sirnagalih, RT 02/ RW 03, Kelurahan Sirnagalih, Kecamatan Indihang, Kota Tasikmalaya. Di sebelah selatan wilayah ini berbatasan dengan Kabupaten Ciamis yang dipisahkan oleh sungai Citandui, sedangkan di sebelah utara berbatasan dengan kampung Leuwidahu, sebelah barat dengan kampung Sirnagalih dan sebelah timur dengan kampung Parakanyasag.

Keberadaan pesantren ini sangat diminati baik oleh Masyarakat sekitar kota Tasikmalaya maupun masyarakat luar kota Tasikmalaya. Para orang tua yang menginginkan anaknya untuk belajar takhfidz al-Qur'an tentunya memiliki harapan agar anaknya belajar ilmu agama, bahkan bisa melanjutkan di sekolah formal tingkat pertama(SMP). Karena di lingkungan pondok, juga berdiri sebuah lembaga pendidikan formal yang diberi nama SMP IT Nurul Iman. Walaupun menggunakan nama Islam Terpadu (IT), bukan berarti bagian dari Jaringan Sekolah Islam Terpadu (JSIT). memiliki visi dan misi sendiri. Pembelajaran yang diterapkan benar-benar memadukan antarailmuagama denganilmu pengetahuan umum.

Pada tahun 2015, jumlah santri takhasus takhfidz usia sekolah dasar (SD) sebanyak 11 anak (6 laki-laki dan 5 perempuan), mereka berasal dari berbagai daerah, seperti Bogor, Pontianak, Banjar dan dari Kota Tasikmalaya sendiri. PP Nurul Iman yang berada di bawah
Yayasan Musaddadiyah Kota Tasikmalaya dipimpin oleh KH.Drs. Dede Khoerudin. Dalam pengelolaan sehari-hari di pesantren, beliau dibantu oleh seorang wakil pemimpin pesantren yang berpendidikan sarjana (S1), dan 10 (sepuluh) ustdz/ustadzah (8 orang berpendidikan SMA/MA/sederajat, 1 orang berpendidikan $\mathrm{S} 1$ dan 1 orang berpendidikan S2).

Pondok pesantren yang berdiri di atas tanah seluas sekitar 2 hektar (ha), memiliki beberapa sarana ataupun fasilitas sesuai dengan kebutuhan. Di antaranya: kobong (asrama) putra 8 lokal, asrama putrid 8 lokal, ruang kelas/madrasah 4 lokal, masjid, 4 kamar mandi/WC putra, 4 kamar mandi/WC putri, ruang dapur, rumah/ bangunan Kyai, aula dan kantin.

\section{Proses Peyelenggaraan Pendidikan Tahfidzul Qur'an}

\section{Pengelolaan Santri}

Pada awal tahun pembelajaran sebelum memasuki pembelajaran takhasus tahfidz harus melalui beberapatahap, yaitu:1) Tahap I; Persiapan (Ibtida') ( 1 tahun); Pada 6 bulan pertama, santri sudah mulai diwajibkan untuk belajar menghafal Juz Amma (Juz 30); 2) Tahap II: Awaliyah ( 1 tahun); dasar-dasar praktek ibadah; dan 3) Tahap III: Tsanawi (target 6 bulan); belajar tentang: 1) Belajar membaca al Qur'an dengan tahsin, 2) Syaratsyarat masuk dunia Tahfidz. Pada masa persiapan tahap ini, santri diwajibkan untuk menghafal surat-surat pilihan yang terdiri dari 5 (lima) surat, yaitu: Al Mulk, Al Waqi'ah, Yasin, Arrahman dan An Naba. 


\section{Metode Menghafal dan Pengaturan Waktu}

Metode menghafal al Qur'an adalah dengan metode "dengar" (Tasmi', Talaqi dan Iqra. Rata-rata setiap hari santri bisa menghafal 5 - 10 ayat. Sesuai dengan dunia anak-anak adalah masa bermain, pelaksanaan hafalan sering menggunakan metode Tasmi' dan dilakukan sambil bermain (misalnya "congklak"). Dalam metode dengar ini, santri diperdengarkan rekaman hafalan Hafidz cilik Internasional terkenal Muhammad Thoha. Dengan strategi sambil bermain justru membuat anak lebih gampang menyerap materi hafalan. Secara kasat mata, sepertinya anak tidak serius mendengarkan rekaman yang sengaja diputar oleh Kyai, tetapi ternyata sebaliknya justru anak lebih cepat hafal.

Dengan metode Talaqi dan Sama'i, yaitu dengan cara seorang Kyai/ustadz membacakan 1 (satu) ayat menirukan, kemudian anak mengulang sampai 20 kali. Setelah mengulang 3 sampai 20 kali, dibaca di depan Kyai/ustadz sampai 10 kali dan lancar, dilanjutkan hafalannya. Untuk bisa melanjutkan ke ayat atau surat berikutnya harus benar-benar sudah hafal ayat/surat sebelumnya secara benar setelah ditahqiq dan ditahsis oleh Kyai atau Umi. Kalaupun beliau berdua terpaksa berhalangan, diserahkan kepada assisten (badal). Hafalan dan bacaan ta'awudz saja bisa sampai 1 minggu. Setoran hafalan dilakukan setiap hari ba'da sholat Shubuh dan ba'da Sholat Ashar, di mana santri dibagi menjadi 5 (lima) kelompok, yaitu: 1) Kelompok Juz Amma, 2) Kelompok Tabaruq (Juz 29), 3) Kelompok Persami'a, 4) Kelompok Yasin, dan 5) Kelompok Al Waqi'ah dan Arrahman.
Ketika setoran hafalan, apabila ada kesalahan (misal bacaan ataupun tajwid) wajah anak diberi colekan "blauw". Ini bukan berarti menghukum atau pemberian sangsi kepada anak, tetapi lebih kepada mengingatkan berapa kali melakukan kesalahan yang harus diperbaiki. Dengan cara itu anak-anak bukannya patah semangat ataupun malu, tetapi diterima dengan senang dan tetap selalu ceria dan semangat. Di samping itu, antar anak yang satu dengan lainnya akan saling mengingatkan. Untuk menghindari banyak kesalahan, maka sebelum setoran ke Kyai anak terlebih dahulu saling setor di antara teman-temannya. Dalam setoran apabila sudah tidak menunjukkan kesalahan/ kekurangan maka anak berhak untuk melanjutkan hafalan pada surat berikutnya.

Pengaturan waktu bagi santri yang sekolah formal (SD): 1) Ba'da Sholat Shubuh dan sholat Maghrib; setoran hafalan; 2) Ba'da Sholat Ashar; pembelajaran Tahsin dan Tajwid; dan 3) Pembelajaran tahsin dan tajwid dilakukan setiap hari sehabis sholat Ashar.

\section{Pencapaian Target dan Penilaian}

Target sampai kelas VI SD adalah santri bisa hafal Al Qur'an 3 (tiga) juz, jadi target setiap tahun adalah hafal 1 (satu) juz. Apabila ada santri yang tidak bisa mencapai target tetap terus diberi semangat dan dihargai. Menurut Kyai, tidak ada anak yang sempurna, setiap anak mempunyai tabiat atau karakter yang berbeda-beda. Oleh karena itu, tidak ada yang namanya sangsi karena memang tidak ada paksaan dan kemampuan anak berbeda. Yang penting 
bagi anak adalah adanya semangat dan kemauan, itu yang harus dihargai.

Pengharagaan bagi santri yang bisa mencapai target pada setiap tahunnya, diantaranya adalah: 1) Bagi yang sudah lulus SD, bisa langsung masuk di SMP IT Nurul Iman tanpa dipungut biaya, 2) Piagam. Selain itu, bagi santri yang sudah mencapai target disarankan secara rutin menyisihkan waktu 1 hari untuk mengulang hafalan 1 (satu) juz. Sedangkan bagi santri yang tidak mencapai target tetap terus diberi semangat dan dipupuk rasa percaya dirinya, serta dibimbing terus sesuai kemampuannya, sehingga anak tidak merasa rendah diri (minder) di depan teman-temannya yang bisa mencapai target.

Laporan hasil Takhfidz al-Qur'an setiap 6 (enam) bulan sekali dalam bentuk buku Laporan Setoran yang diserahkan kepada orang tua santri. Kategori penilaian terdiri dari: nilai C (Jelek "Qobih"), B (Sedang "Jayyid"), A (Bagus "Jayyid Jiddan") dan Istimewa (Mumtaz). Nilai C (jelek) harus diulang.

\section{Out Put Lulusan}

Sudah banyak alumni pondok pesantren Nurul Iman Musyadaddiyah Takhfidz Al Qur'an yang menjadi imam masjid di tempat-tempat penting, seperti: a) Imam Masjid Baitur Rahman Gedung DPR MPR Senayan Jakarta (Shofwan Amiruddin), b) Imam Masjid dan Muadzin tetap di masjid Cilandak Jakarta, c) Imam Masjid Raya di Bogor, dan 4) Imam masjid di Kabupaten Karimun, Propinsi Kepulauan Riau. Alumni PP Nurul Iman Musyadadiyah Takhfidz membentuk suatu wadah yang diberi nama HASBINI (Himpunan Anak Santri Binaan
Nuru Iman) “Allah Yang Mencukupi”. Mereka mengadakan pertemuan setiap tahun pada tanggal 5 Syawal, bertepatan pada acara wisuda santri.

\section{Faktor Pendukung dan Penghambat}

Menurut pimpinan pesantren, faktor pendukung penyelenggaraan pendidikan Tahfidzul Qur'an yang utama adalah kemauan anak yang sangat kuat dan anak tidak merasa terpaksa. Kemauan atau niat merupakan factor pendorong yang dilator belakangi oleh keyakinan akan nilai-nilai spiritual. Niat dalam menghafal al-Qur'an harus ikhlas semata karena Allah semata, bukan mengharapkan pujian dari orang lain, penghormatan atau tujuan karena duniawi. Niat sangat berpengaruh pada hasil yang diperoleh seseorang dalam setiap perbuatannya, bahkan niat juga menjadi penentu nilai suatu perbuatan. Faktor pendukung lainnya adalah motivasi atau dorongan dari orang tua, dan dorongan dari diri anak itu sendiri karena ingin membahagiakan orang tua.

Sedangkan faktor penghambatnya adalah: 1) Terkadang sikap orang tua yang terlalu memanjakan anak, tidak tega ataupun terlalu sering dikunjungi/dijenguk, sehingga anak menjadi tidak mendiri, 2) Dunia anak ataupun fitrah anak yang senang bercanda, yang kadang mengganggu temannya yang sedang belajar, dan 3) Biaya.

\section{Pengelolaan Pendidikan Tahfidzul Qurán: Sebuah Analisis}

\section{Aspek Perencanaan (Planning),} Perencanaanyangbaiktentunyadirumuskan terlebih dahulu, dengan memperhatikan berbagai hal yang berkaitan dengan arah dan 
tujuan lembaga.Pondok Pesantren Tahfidzul Qur'an Nurul Iman sudah menunjukkan perencanaan yang jelas bagi lembaganya. Hal itu terlihat dengan sudah adanya rumusan arah yang jelas bagi lembaganya, yang diwujudkan dengan visi yang dimiliki. Untuk mencapai visi yang dicanangkan tersebut, sudah dioperasionalkan dalam bentuk jabaran misi lembaga, sampai pada rumusan tujuan penyelenggaraan pendidikan yang sudah jelas. Yaitu: 1) Mencetak generasi muslim yang mampu menghafal al Qur'an dalam jangka waktu tertentu; 2) Mencetak generasi muslim yang mencintai al-Qur'an sekaligus mengamalkan dalam kehidupan sehari-hari, sehingga terbentuk generasi yang berahlakul karimah yang dijiwai oleh nilai-nilai al-Qur'an; dan 3) Mengamalkan ilmunya bagi orang lain (dakwah, pelayanan umat, dsb.).

Dalam proses mencapai arah dan tujuan lembaga, perlu adanya upaya ataupun strategi yang memudahkan bagi para pengelolanya untuk menjalankan proses pendidikan. Strategi disusun dengan jelas, sehingga mempermudah dalam proses mendidik anak dalam menghafal dan mencintai al-Qur'an. Yaitu dengan: 1) Memperkenalkan al-Qur'an agar dicintai dan mencintai orang yang membacanya; 2) Selalu bersama dengan al Qur'an di dalam situasi apapun; dan 3) Mau memberikan yang diterima kepada orang lain walaupun hanya 1 (satu) ayat.

Dari segi keluasan dan waktu, sudah memperlihatkan adanya pemisahan atau penjelasan antara rencana jangka panjang (strategis) dengan rencana jangka pendek (operasional). Artinya, target pendidikan sudah dirumuskan sejak awal dan sudah disosialisasikan kepada para santri dan juga orang tua. Misal, dalam jangka pendek santri sudah bisa hafal 1 ayat/hari, sedangkan jangka panjang adalah santri bisa hafal al-Qur'an 30 juz dalam jangka waktu 2 - 5 tahun.

Mencermati arah, tujuan dan strategi lembaga yang tertuang dalam visi, misi dan strategi, sudah menunjukkan sebuah perencanaan yang factual (realistis), logis dan rasional, fleksibel, komitmen dan komprehensif. Faktual, artinya rumusan tujuan sesuai dengan fakta dan wajar untuk dicapai sesuai kondisi dan usia santri yang masih anak-anak. Logis dan rasional, maksudnya rencana yang dirumuskan dapat diterima oleh akal, sehingga mudah dijalankan oleh pengelolanya (misal anak bisa hafal 1 ayat/hari). Fleksibel, artinya rumusan perencenaan tidak kaku dan dapat beradaptasi dengan perubahan di masa yang akan datang (santri tidak hanya hafal al-Qur'an, tetapi juga dibekali dengan jiwa kemandirian dan keterampilan teknologi komunikasi dan mampu berbahasa asing). Komitmen; maksudnya masing-masing pimpinan mempunyai komitmen yang jelas dan kuat yang diiukuti pula para pengelola (pengasuh) lainnya. Komprehensif, artinya menyeluruh dan mengakomodasi aspekaspek yang terkait langsung maupun tidak langsung dengan lembaga (santri dibekali ilmu agama dan ilmu pengetahuan umum).

Begitu juga, Rencana Pelaksanaan Pembelajaran (RPP), Rancangan Anggaran, Pendapatan dan Belanja Pondok (RAPBP) termasuk sumber dana sudah terinci dalam sebuah dokumen Program Pondok secara rutin setiap tahun.

\section{Aspek Organisasi (Organizing),} Organisasi merupakan bagian yang tidak terpisahkan dengan kehidupan dan 
penghidupan manusia. Mengorganisasi adalah proses pengelompokan kegiatankegiatan untuk mencapai tujuan-tujuan dan penugasan setiap kelompok kepada seornag manajer, yang mempunyai kekuasaan, yang perlu untuk mengawasi anggota-anggota kelompoknya Pengorganiasian dilakukan untuk menghimpun dan mengarut semua sumber-sumber yang diperlukan, termasuk manusia, sehingga pekerjaan yang dikehendaki dapat dilaksanakan dengan berhasil baik. Mengorganisasi perlu karena kerja yang akan dilakukan cukup banyak untuk ditangani oleh seorang saja.

Sebagaimana dalam perencanaan, tujuan organisasi harus jelas dan dapat dipahami secara jelas oleh para anggotanya dan dapat diterima oleh anggotaanggotanya. Tujuan dari lembaga tahfidz PP Tahfidzul Qur'an Nurul Iman, Tasikmalaya, secara sederhana dapat dipahami oleh unsur-unsur yang terdapat dalam lembaga tersebut, seperti: pimpinan, pengasuh (ustadz/ustadzah/pendidik), santri dan juga orang tua santri (masyarakat). Ketika orang tua santri memasukkan anaknya untuk belajar di lembaga tersebut sudah disosialisasikan tentang tujuan dan program pendidikan yang akan diikutinya. Dengan demikian, mereka (orang dan santri) sudah paham secara jelas berbagai peogram dan ketentuan-ketentuan yang harus ditaati. Begitu juga dengan para pengelola (pengasuh/guru) sudah memahami tugas dan kewajiban sebagai seorang pendidik bagi santri yang masih usia anak sekolah dasar/dini.

Dengan adanya pemahaman dan kejelasan akan tujuan dan kewajiban dari para pengasuh, santri dan juga orang tua, maka pendelegasikan atau pembagian tugas semakin mudah dilakukan oleh pimpinan. Apalagi di sebuah lembaga pendidikan pondok pesantren, ketaatan dan kepatuhan dari para unsur pondok terhadap lembaga terutama pimpinan (Kyai) tidak perlu diragukan lagi. Begitu juga dalam pengelolaan terhadap santri dan juga orang tua, juga tidak terlalu mengalami kesulitan,. Artinya, pembagain tugas dan kewajiban dapat berjalan lancar.

\section{Aspek Pelaksanaan (Actuating),} Kemampuan seorang pimpinan dalam sebuah organisasi atau lembaga sangat berpengaruh pada gerak langkah para personalnya dalam melaksanakan tugas dan kewajiban. Sebagaimana dikemukana di atas, ketaatan dan kepatuhan dari para unsur pondok terhadap pimpinan (kyai) sangat kuat dan tidak diragukan lagi. Dengan demikian, para personal, seperti: pengasuh, pengurus, santri dan juga orang tua santri semangat dan antusias dalam menjalankan tugas dan kewajiban. Para santri, didukung dengan kemauan yang kuat juga adanya motivasi dan arahan "wejangan" dari Kyai (misal terhadap para guru/ustadz/ pengasuh Kyai selalu berpesan agar dalam mengajar dan mendidik anak hendaknya dilakukan dengan penuh keihlasan tanpa mengharapkan imbalan terutama yang sifatnya materi dan harus sabar menghadapi berbagai macam karakter anak/santri), melancarkan proses pendidikan terutama dalam menghafal al-Qur'an. Begitu juga dengan pengasuhnya, walaupun dengan "imbalan" yang mungkin belum mencukupi kebutuhan hidupnya tapi tetap semangat untuk mendidik para santri.

Komunikasi antara individu di dalam pondok berjalan cukup efektif. Hal itu disebabkan aleh kemampuan Kyai/pimpinan 
dalam membimbing, mengarahkan, mengatur segala kegiatan yang telah diprogramkan oleh lembaga. Di samping komunikasi yang efektif dan motivasi dari pimpinan, pergerakan lembaga juga dipengaruhi oleh factor kemampuan dari individu (pengasuh, santri) dan kejelasan informasi (perintah yang dioperasionalkan dalam "job description"), mudah dipahami oleh pengasuh dan dan juga santri.

Dalam proses pelaksanaan hafalan para santri yang masih usia sekolah (usia 6 - 12 tahun), menunjukkan adanya penyesuaian dan memperhatikan kebutuhan dunia anak, walaupun tidak sepenuhnya. Misal, dalam proses hafalan dengan metode tertentu (sama'i "mendengar"), sambil bermain, berlari dan bahkan bercanda. Kelihatannya mereka kurang serius dalam menghafal, tetapi ternyata dengan menghafal sambil bermain justru lebih mudah dilakukan oleh anak dan tertanam kuat dalam ingatannya.

Kemampuan anak berbeda-beda, ada yang pintar (cepat menghafal), sedang dan lambat. Oleh karena itu, tidak pernah ada paksaan terhadap anak, bahwa anak harus mencapai target yang telah ditentukan. Bagi anak yang mempunyai kemampuan cepat (pintar) diberi keluasaan untuk melanjutkan ke jenjang/hafalan selanjutnya, sedangkan bagi anak yang lambat tetap diberi semangat dan tidak ada sangsi yang merugikan atau mematahkan semangat anak. Bagi pimpinan, yang utama dari seorang anak dalam hafalan al Qur'an adalah kemauan yang kuat dan mencintai al Qur'an dengan sepenuh hati.

Dalam pelaksanaan setoran hafalan, apabila ada anak yang kurang atau salah dalam hafalannya maka sangsinya adalah muka "diblau", yang kadang dilakukan oleh
Kyai sendiri dan kadang pula sesama santri. Sangsi atau "hadiah" tersebut semata-mata sebagai peringatan anak bahwa masih harus diulang dan diperbaiki lagi. Tidak ada rasa sedih ataupun kurang percaya diri dari mereka yang kena sangsi, malah kadang pada tertawa dan saling "meledek".

Menurut Gestalt, bahwa seseorang belajar jika mendapatkan insight, timbulnya insight (pemahaman) tergantung pada: kesanggupan, pengalaman, taraf kompleksitas, latihan dan trial and eror (Sardiman, 2008:30-31). Mencermati proses pembelajaran hafalan al-Qur'an di PP Nurul Iman, kota Tasikmalaya dengan menggunakan teori Gestalt, ada beberapa aspek yang terpenuhi, diantaranya adalah: kesanggupan, latihan, dan trial and eror. Aspek kesanggupan, anak tidak dipaksakan untuk mencapai target yang sudah dirumuskan, akan tetapi disesuaikan dengan kemampuan/kesanggupan dan potensi individu. Bagi anak yang mampu diberi kesempatan untuk melanjutkan ke tahap berikutnya, sementara bagi anak yang mengalami kelambatan tetap dihargai dan diberi semangat. Dalam aspek ini juga terkandung makna bahwa sebenarnya tidak ada anak yang pandai dan anak bodoh, yang benar adalah kemampuan dan potensi anak berbeda-beda. Tugas seorang pembimbing (ustadz/ustadzah) adalah membimbing anak kea rah suatu tujuan yang lebih baik/ tinggi. Dalan pendekatan belajar tuntas 'mastery learning', perbedaan kemampuan/ kesanggpan dan bakat anak termasuk salah satu yang aspek yang harus diperhatikan, karena berpengaruh pada pencapaian pembelajaran penuh/tuntas. (Nasution, 1992: 37-43). 
Aspek latihan dan trial and eror., dengan seringnya anak mengulang hafalan ayat sampai puluhan kali maka anak semakin tinggi kemampuann hafalannya. Begitu juga, dengan seringnya saling uji kemampuan antar anak dalam hal setoran hafalan, maka akan semakin tinggi kemampuan. Di samping itu, kematangan bersosialisai, komunikasi, disiplin juga bisa ditingkatkan melalui metode ini.

Dengan belajar dalam suasana perasaan dan hati senang karena tidak ada paksaan, akan mempererat respons dan hubungan stimulus. Karena itu, dengan upaya atau cara memuji, menghargai, membesarkan hati terutama terhadap anak yang mengalami kelambatan atautidakmencapaitarget dalam waktu tertentu sebagaimana yang dilakukan oleh pimpinan pesantren merupakan salah satu faktor yang berpengaruh positif dalam pencapaian tujuan belajar (takhfidz). Metode tersebut sesuai dengan teori Konektionisme dari Thorndike kegiatan reinforcement, seperti memuji dan membesarkan hati sangat diperlukan dalam kegiatan belajar, (Thorndike dalam Sardiman, 2008: 33).

Sebagaimana dijelaskan di awal, bahwa syarat menghafal al Qur'an adalah: 1) Niat yang ikhlas, 2) Memiliki keteguhan dan kesabaran, 3) Istiqomah (kontinuitas), dan 4) Menjauhkan diri dari maksiat dan sifat tercela. Empat syarat tersebut, dari awal anak (santri) memulai masuk pondok sudah ditekankan dan diterapkan dalam proses belajar dan menghafal al Qur'an.

Aspek Pengawasan (Controlling), Fungsi pengawasan sebagai fungsi manajemen terakhir dalam sebuah lembaga dan sangat menentukan pelaksanaan proses mnajemen. Pengawaan sebagai proses pemantauan, penilaian dan pelaporan rencana atas pencapaian tujuan yang telah ditetapkan untuk tindakan perbaikan dan penyempurnana selanjutnya.

Pengawasanyang dilakukan oleh pondok pesantren dilakukan setiap saat terutama oleh pimpinan. Aktifitas santri sehari-hari di pondok selalu dalam pantauan pimpinan, baik itu perilaku, pelaksanaan ibadah sholat dan juga hafalan. Sesungguhnya dalam sebuah organisasi, yang dibutuhkan tidak hanya pengawasan tetapi juga pengendalian. Karenakewenanganantarkeduanyaberbeda, pengawas sebatas hanya membei saran, sedangkan tindak lanjutnya dilakukan oleh pengendalian. Jadi pengendalian fungsinya lebih luas dari pada pengawasan. Namun demikian, pada umunya penggunaan atau fungsi pengawasan dan pengendalian sering dilakukan oleh satu seorang atau tim yang sama.

Untuk pengawasan dan penilaian terhadap lembaga dan juga proses pendidikan yang telah dilakukan, biasa dilakukan pada akhir semester dan juga akhir tahun. Dari pengawasan dan penilaian tersebut, dapat diidentifikasi beberapa factor pendukung dan penghambat, yang dapat dijadikan dasar atau pijakan untuk menentukan program kselanjutnya.

\section{PENUTUP}

Berdasarkan uraian dan pembahasan tersebut di atas, maka dapat diambil kesimpulan, bahwa penyelenggaraan pendidikan Takhfidzul Qur'an di Pondok Pesantren Nurul Iman, mulai dari perencanaan, pengorganisasian, pelaksanaan dan pengawasan 
(pengendalian),

memperlihatkan penyelenggaraan yang profesional.

Diawali dengan perencanaan (planning), semuanya sudah memiliki rumusan yang jelas tentang visi, misi, tujuan, target dan strategi pendidikan. Dengan adanya arah dan tujuan yang jelas, maka akan memudahkan para pengelola untuk mengakualisasikan program kerja yang sudah dirancang. Dalam pengorganisasiani/penggerakan (Organizing); adanya pemahaman dan kejelasan akan tujuan dan kewajiban dari para pengasuh, santri dan juga orang tua, maka pendelegasikan atau pembagian tugas semakin mudah dilakukan oleh pimpinan. Di samping itu, "Kharisma" seorang Kyai di pondok pesantren mempermudah dalam menggerakkan para pengelola dalam menjalankan program lembaga. Selanjutnya dalam proses pelaksanaan (Actuating); kemampuan dan "kharisma" pimpinan (Kyai) sangat berpengaruh pada gerak langkah para pengelola, ustadz/ustadzah/ pendidik dan santri dalam melaksanakan tugas dan kewajiban. Di samping itu, adanya keinginan/kemauan yang kuat dari santri dan komitmen dari para ustadz/ustadzah, maka program pendidikan Takhfidzul Qur'an dapat berjalan lancar. Komunikasi antara individu di dalam pondok dan juga rumah takhfidz yang efektif, juga menjadi salah satu factor pendukung dalam proses pendidikan Takhfidzul Qur'an. Dalam proses pembelajaran Takhfidzul Qur'an, dengan menggunakan beberapa metode dan pendekatan, sehingga anak tetap gembira dan tidak ada paksaan, tercipta dalam lingkungan pendidikan terutama di pondok. Terakhir pengawasan (Controlling); fungsi pengawasan sebagai fungsi manajemen terakhir dalam sebuah lembaga dan sangat menentukan pelaksanaan proses manajemen. Pengawasan yang dilakukan oleh pondok pesantren dan rumah takhfidz dilakukan setiap saat terutama oleh pimpinan. Aktifitas santri sehari-hari di pondok selalu dalam pantauan pimpinan, baik itu perilaku, pelaksanaan ibadah sholat dan juga hafalan. Untuk pengawasan dan penilaian terhadap lembaga dan juga proses pendidikan yang telah dilakukan, dilakukan pada akhir semester dan juga akhir tahun.

Faktor Pendukung penyelenggaraan pendidikan Tahfidzul Qur'an meliputi: 1) Kemauan anak yang sangat kuat dan anak tidak merasa terpaksa, 2) Motivasi dari orang tua, 3) Komitmen yang kuat dari para pengasuh, 4) Lingkungan pondok yang tenang dan nyaman., 5) Kerjasama antara lembaga (pondok) dengan orang tua dan masyarakat sekitar. Untuk pondok pesantren Nurul Iman, selain factorfaktor tersebut, factor pendukung lainnya adalah: 1) Perhatian dari pemerintah (Kementerian Agama Kota Tasikmalaya dan lembaga terkait), baik moril maupun materiil, dan 2) Kerjasama antar pengelola TPQ yang tergabung dalam organisasi FKPQ (Forum Komunikasi Pendidikan alQur'an). Sedangkan faktor penghambatnya adalah: 1) Terkadang sikap orang tua yang terlalu memanjakan anak, tidak tega ataupun terlalu sering dikunjungi/dijenguk, sehingga anak menjadi tidak mendiri, 2). Kekurangan tenaga pendidik, jumlah santri/siswa dengan tenaga pendidik tidak seimbang. Untuk mengatasi hambatan tersebut, dengan memberdayakan para badal ataupun siswa senior (kakak kelas), 3) Kadang sering muncul sifat malas dari anak, dan 4) Lingkungan tempat tinggal sebagian 
santri yang kurang/tidak mendukung, yang bisa merusak hafalan anak.

Beberapa hal yang dapat disarankan adalah:1)Penguatan organisasiatau lembaga pendidikan seperti: podok pesantren dan rumah takhfidz perlu ditingkatkan, baik melalui peningkatan kualitas maupun kuantitas sumber daya manusia (pengelola/ ustadz/ustadzah) maupun kerjasama antar lembaga pendidikan terkait. 2) Proses pendidikan Takhfidzul Qur'an dengan penerapan metode hafalan dan pendekatan pembelajaran yang bervariasi sehingga membuat anak tetap gembira, perlu dipertahankan dan lebih ditingkatkan lagi, sehingga bisa menjadi panutan bagi lembaga pendidikan Takhfidzul Qur'an lainnya., dan 3) Pendidikan Takgfidzul Qur'an bagi anak usia dini (usia sekolah dasar) perlu mendapat perhatian yang serius dari pemerintah (dhi. Kementerian Agama). Karena anak adalah asset umat, sebagai generasi penerus penjaga al-Qur'am yang harus terus dipupuk dan ditumbuh kembangkan, agar dapat menjadi inspirasi bagi anak-anak lainnya.

\section{UCAPAN TERIMA KASIH}

Terima kasih penulis sampaikan kepada Kementerian Agama Kota Tasikmalaya, terutama kepada Kepala Seksi PAKIS (Pendidikan Keagamaan dan Pondok Pesantren Drs.H. Suryana dan Leni (Staf Seksi PAKIS) yang telah berkenan meluangkan waktu dan tenaganya untuk menemani penulis di lapangan (pondok pesantren dan rumah takhfidz). Di samping itu kepada pimpinan Pondok Pesantren Nurul Iman (KH. Dede Khoiruddin), pimpinan Rumah Takhfidz Darul Ilmi cendekia (Ustad Ahamad dan isteri), dan ketua FKPQ (Forum
Komunikasi Pendidikan al Qur'an) Kota Tasikmalaya, yang telah berkenan menerima dan meluangkan waktunya kepada penulis sebagai peneliti.

Tak lupa penulis sampaikan terima kasih kepada Kepala Balai Penelitina dan Pengembangan Agama Jakarta, beserta tata usaha yang telah menyiapkan segala keperluan administrasi penelitian, dan kepada para peneliti yang telah berperan aktif dalam diskusi tentang penelitian Pendidikan Takhfidzul Qur'an.

\section{DAFTAR PUSTAKA}

Ahsin, W. Al Hafizh. (2000); Bimbingan Praktis Menghafal Al Qur'an, Jakarta: bumi Aksara.

Azis, Abdul \& Abdul Rauf, (2004) dalam bukuinsfirasi.blogspot.com, diakses tanggal 27 Mei 2015.

Arikunto, Suharsimi., (2006). Prosedur Penelitian Suatu Pendekatan Praktis, Jakarta: PT. Rineka Cipta.

Badwilan Ahmad Salim, (2009). Panduan Cepat Menghafal Al Qur'an, Yogyakarta: Diva Press.

Brantas, Drs.M.Pd., (2009). Dasar-dasar Manajemen, Bandung: Alfabeta.

Departemen Agama RI, (2006). Al-Qur'an Dan Tejemahnya. Jakarta: CV. Nala dana

Hamalik, Omar, Prof.Dr., (2008). Proses Belajar Mengajar, Bumi Aksara.

Malayu S.P. Hasibuan, 2011, Manajemen Dasar Pertimbangan dan Masalah, Jakarta: PT. Bumi Aksara.

Moeleong, Lexy, (2005). Metode Penelitian Kualitatif, Bandung: PT. Remaja Rosdakarya. 
Munjahid, Tanpa tahun; Strategi menghafal Al Qur'an 10 Bulan Khatam, Yogyakarta: Idea Press.

Nasution, Prof.Dr.S., (2008). Berbagai Pendekatan Dalam Proses Belajar \& Mengajar, Jakarta:

Bumi Aksara..

Raghib al Sirjani dalam M.Sofwan - 2014 digilib.unisby.ac.id, diakses tanggal 27 Mei 2015).

Sardiman, A.M., Interaksi dan Motivasi Belajar Mengajar, Jakarta: PT. Raja Grafindo Persada, 20.

Slavin, Robert E. (2011). Psikologi Pendidikan Edisi ke Sembilan. PT Indeks; Jakarta. dalam http://misbariumsida. blogspot.co.id/2014/01/fase-faseperkembangan-anak-sekolah.html.

Sudjana, (2004), Manajemen Program Pendidikan, Bandung: Falah Production.
Sugianto, Ilham Agus. Kiat Praktis Menghafal Al Qur'an, Bandung: Munjahid press.

Syaiful. Dr.H. M.Pd., (2009) Manajemen Strategik Dalam peningkatan Mutu Pendidikan, Bandung: Alfabeta.

Terry, George R. Ph.D dalam http:// lhynnadisini.blogspot.com, 01 April 2012, diakses tanggal 04 September 2016.

Terry \& Leslie, (2013). Dasar-dasar Manajemn, Penerjemah: G.A. Ticoalu, Jakarta: PT. Bumi Aksara.

Tisnawati, Erni Sule \& Kurniawan Saefullah, (2005). Pengantar Manajemen, Jakarta: Prenada Media.

Yunus, Mahmud. (1972). Kamus Arab Indonesia, Jakarta: Hidakarya Agung.

Yusuf, Musfirotun, (2012), Manajemen Pendidikan, Pekalongan: STAIN Pekalongan Press 